\title{
結晶粒微細化強化と析出強化の並立
}

\author{
堀田 善治*,**. 廣澤 涉一 *** \\ 松田 健二 $* * * *$. 寺田 大将*****
}

Journal of The Japan Institute of Light Metals, Vol. 62, No. 11 (2012), 398-405

(C) 2012 The Japan Institute of Light Metals

\section{Simultaneous strengthning due to grain refinement and fine precipitation}

\author{
Zenji HORITA*,**, Shoichi HIROSAWA*** \\ Kenji MATSUDA ${ }^{* * * *}$ and Daisuke TERADA*****
}

Keywords: grain refinement, precipitation hardening, severe plastic deformation, strength, ductility

\section{1.はじめに}

析出強化, 結晶粒微細化強化は, 固溶強化とともにアルミ ニウム（Al）合金では基本的な強化法である。しかし，それ ぞれの強化法が単独で利用されることはあっても，同時に実 現することは極めて難しい状況にある。これは，結晶粒を微 細にしたまま溶質原子を過飽和状態にし，さらに微細結晶粒 内に細かい粒子を析出分散させることが難しいことによる。 近年，形状不変の巨大ひずみ加工技術を使って結晶粒がサブ ミクロンレベルに超微細化されている1) 5)。この方法は合 金種を問わずに強制的に微細粒化でき，溶体化処理なしでも 第2相粒子を再固溶させ過飽和状態にしてしまうことも可能 である。しかし，加工に伴い大量に導入された格子欠陥のた めに時効処理中に析出が速く進行したり，粒界や転位等の格 子欠陥に優先的に析出して粒子が粗大化してしまうことがあ る。本解説は，析出強化型アルミニウム合金を巨大ひずみ加 工することで，結晶粒を超微細化し，結晶粒微細化強化と析 出強化を同時に実現して強度・延性など力学特性に優れた合 金開発ができないか，その可能性についてまとめるものであ る。

巨大ひずみの導入を可能にするためには，加工しても断面 形状が変化しない形状不変加工法が有効である。このような 形状不変加工法の代表的なものとして ECAP (Equal-Channel Angular Pressing) 法 ${ }^{6}$, HPT (High-Pressure Torsion) 法 ${ }^{7)}$, ARB (Accumulative Roll Bonding) 法 ${ }^{8)}$, MDF (Multi Directional Forging) 法9）などが知られている ${ }^{1) \sim 5)}$ 。中でも HPT 法は高圧下の拘 束条件で巨大ひずみが付与できるため，延性の小さい試料で
も，また高強度の試料でも利用できる特徵がある。 HPT 法で は円盤状やリング状の試料が用いられるが10), 最近では HPT 法と同様に高圧を付与しながら角状試料に適用できる

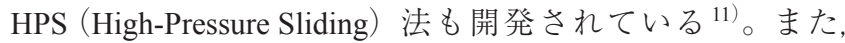
一方では液体窒素中の極低温下で圧延加工して結晶粒を超微

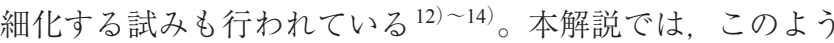
な低温強加工後の時効挙動の例も含めてまとめることにし た。時効析出強化合金として $\mathrm{Al}-\mathrm{Cu}(2000)$ 系, Al-Mg-Si (6000) 系, $\mathrm{Al}-\mathrm{Zn}-\mathrm{Mg}-\mathrm{Cu}$ (7000) 系, $\mathrm{Al}-\mathrm{Li}-\mathrm{Cu}-\mathrm{Mg}$ 系, $\mathrm{Al}-\mathrm{Ag}$ 系合金を対象とした。いずれも，溶体化状態で巨大ひずみ加 工し結晶粒をサブミクロンレベルに超微細化した後の時効挙 動を比較している。

\section{2. $\mathrm{Al}-\mathrm{Cu}$ 系合金}

Cheng ら ${ }^{15)}$ は2024 合金を溶体化処理（766〜813 K, 1 〜 10h）し，123Kの極低温で厚さが半分になるまで圧延して 時効した。図1に示されるように，極低温で圧延すると硬さ

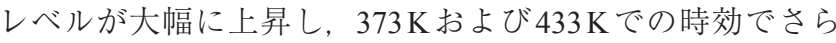
に硬さ増加がみられる。TEM観察から，この硬さレベルの 上昇は微細な亜結晶粒の形成と, 時効により覀結晶粒内にナ ノサイズの $\mathrm{S}^{\prime}\left(\mathrm{Al}_{2} \mathrm{CuMg}\right)$ 相が生成したためと結論されてい る。極低温加工で結晶粒組織（この場合亚結晶粒）を微細に し，ナノ粒子が都合よく転位上に析出したためと解釈されて いる。図2は引張試験による応力ーひずみ曲線を示したもの で，極低温加工後に時効した試料で，強度も伸びも同時に改 善することが示される。一方, Tsuji ら 16) は, Al-2 mass\% Cu 合金を過飽和固溶体にした後，室温でARB加工を行ってマ

*九州大学大学院工学研究院（テ819-0395 福岡県福岡市西区元岡 744番地)。Department of Materials Science and Engineering, Faculty of Mechanical Engineering, Kyushu University (744 Motooka, Nishi-ku, Fukuoka-shi, Fukuoka 819-0395).

**九州大学 カーボンニュートラル・エネルギー国際研究所（福岡市）。WPI, International Institute for Carbon-Neutral Energy Research (I2CNER), Kyushu University (Fukuoka-shi, Fukuoka).

*** 横浜国立大学大学院工学研究院 (横浜市)。Department of Mechanical Engineering and Materials Science, Yokohama National University (Yokohamashi, Kanagawa).

*****富山大学大学院理工学研究部（富山市)。Graduate School of Science and Engineering for Research, University of Toyama (Toyama-shi, Toyama).

******京都大学大学院工学研究科材料工学専攻 (京都市)。Graduate School of Engineering, Department of Materials Science and Engineering, Kyoto University (Kyoto-shi, Kyoto).

受付日：平成24年9月7日＼cjkstart受理日：平成24年9月24日 


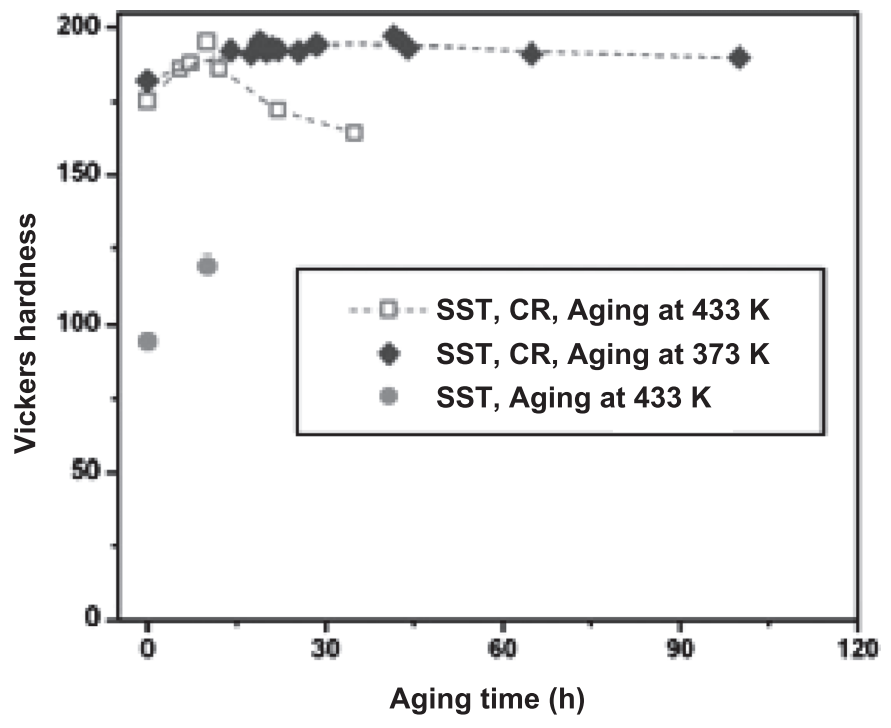

図 1 極低温加工した 2024 合金の $373 \mathrm{~K}$ と $433 \mathrm{~K}$ での時 効に伴う硬さ変化 ${ }^{15}$

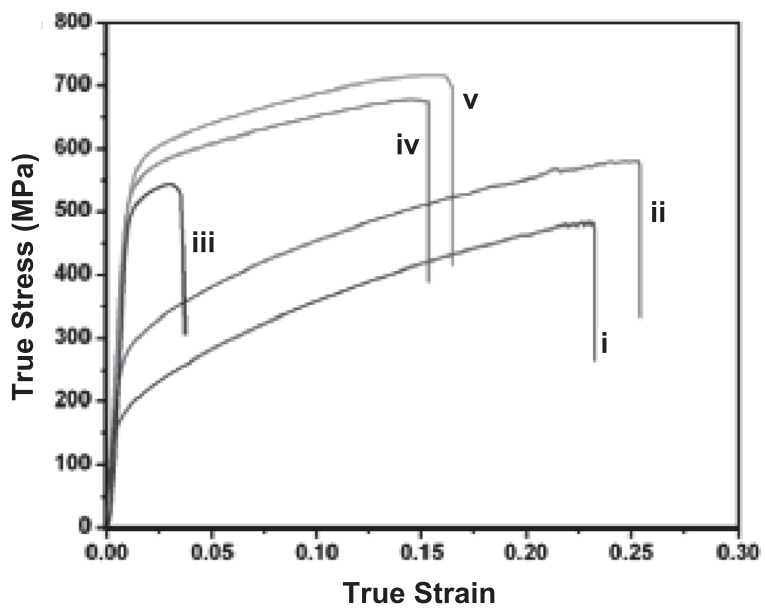

図2 2024 合金の応力ーひずみ曲線 ${ }^{15)}$ ：(i) 溶体化処 理 (SST), (ii) SST 後 $433 \mathrm{~K}$ で $10 \mathrm{~h}$ 時効, (iii) SST 後極低温加工, (iv) SST 後極低温加工L $433 \mathrm{~K}$ で $13 \mathrm{~h}$ 時効, (v) SST 後極低温加工し $373 \mathrm{~K}$ で $100 \mathrm{~h}$ 時効 15)

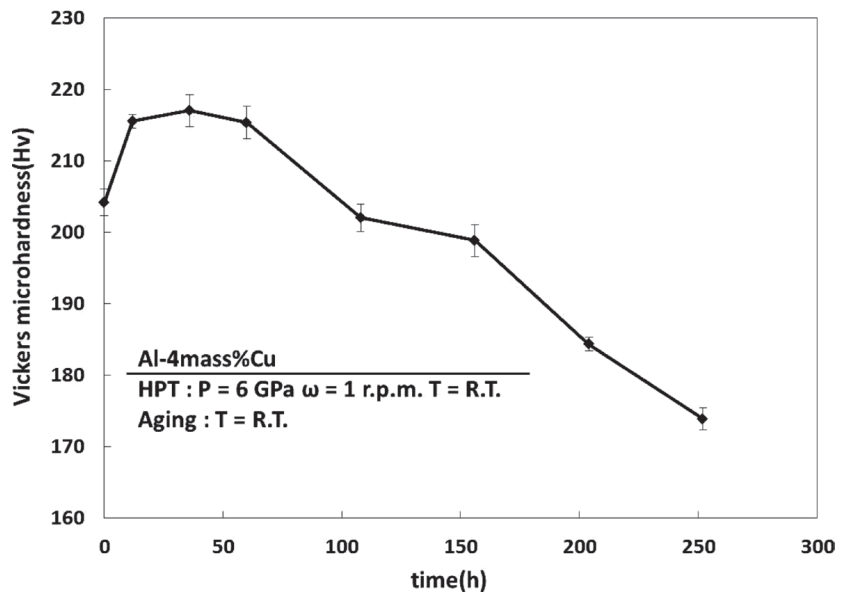

図3 溶体化処理後 HPT 加工した $\mathrm{Al}-4$ mass $\% \mathrm{Cu}$ 合金の 室温における硬さ変化 ${ }^{17}$
トリクスを超微細粒組織にし, その後時効析出挙動を調べ た。時効温度が $463 \mathrm{~K}$ と高いことから，非整合析出物が粒界 に析出し，また回復・粒成長も生じて，時効時間の経過とと もに硬さは単調に減少する結果となった。

米永と堀田 ${ }^{17)}$ は $\mathrm{Al}-4$ mass $\% \mathrm{Cu}$ 合金を $803 \mathrm{~K} て ゙ 5$ 時間溶体 化処理後HPT加工して結晶粒を $210 \mathrm{~nm}$ に超微細化したのち, 室温(約 $300 \mathrm{~K}$ ) に放置して硬さの増加を確認した。図3に 示すようにHPT加工で硬さが $200 \mathrm{HV}$ に達し，さらに 1.5 日の 室温時効で $215 \mathrm{HV}$ まで増加した。室温時効材の TEM 観察か ら $\mathrm{Al}_{2} \mathrm{Cu}$ の金属間化合物に対応する回折斑点を確認してい る。

\section{Al-Mg-Si系合金}

Kim $5^{18), 19)}$ は6061 合金を溶体化処理 $(803 \mathrm{~K}, 4 \mathrm{~h})$ し, 398K でECAP加工して，3つの異なる温度 $(373,413,448 \mathrm{~K})$ で時 効処理した。373K 時効後の硬さ試験結果は図4に示すよう で，明瞭な硬さ増加が確認される。ただし，硬さレベルと硬 化量は 4 パスの試料が最も大きく，これ以上にパス回数を増 した試料では，硬さレベルと硬化量ともに減少している。 $413 \mathrm{~K} や 448 \mathrm{~K}$ でも ECAP加工材の時効硬化は確認されるが, 時効温度が高くなるほど硬さレベルや硬化量はパス回数の低 い試料で高くなり, パス回数が高い試料では時効初期から軟 化が観察される ${ }^{18)}$

TEM観察によれば，結晶粒径はECAP後で約 $400 \mathrm{~nm}$ で, 図5に示されるように，時効後も結晶粒は粗大化しておら ず，結晶粒微細化強化と析出強化の並立がみられる。析出相 は直径 $20 〜 30 \mathrm{~nm}$ の球状粒子となっており均一に分散した状 態にある。溶体化材の時効では析出相は針状 $\left(\beta^{\prime \prime}\right)$, ロッド 状 $\left(\beta^{\prime}\right)$ ，ディスク状 $(\beta)$ であるのに対して ECAP試料では 球状となり対照的である。12パスよりも 4 パス材の方が強度 が高く時効性も高いことから，並立強化を実現させるには付 与ひずみの適切な制御が重要であることが示唆される。図6 は引張試験の結果で，硬さ試験と同様に，ECAPままよりも ECAP後に時効した方が強度が増加する ${ }^{19)}$ 。Sauvageら 20)も

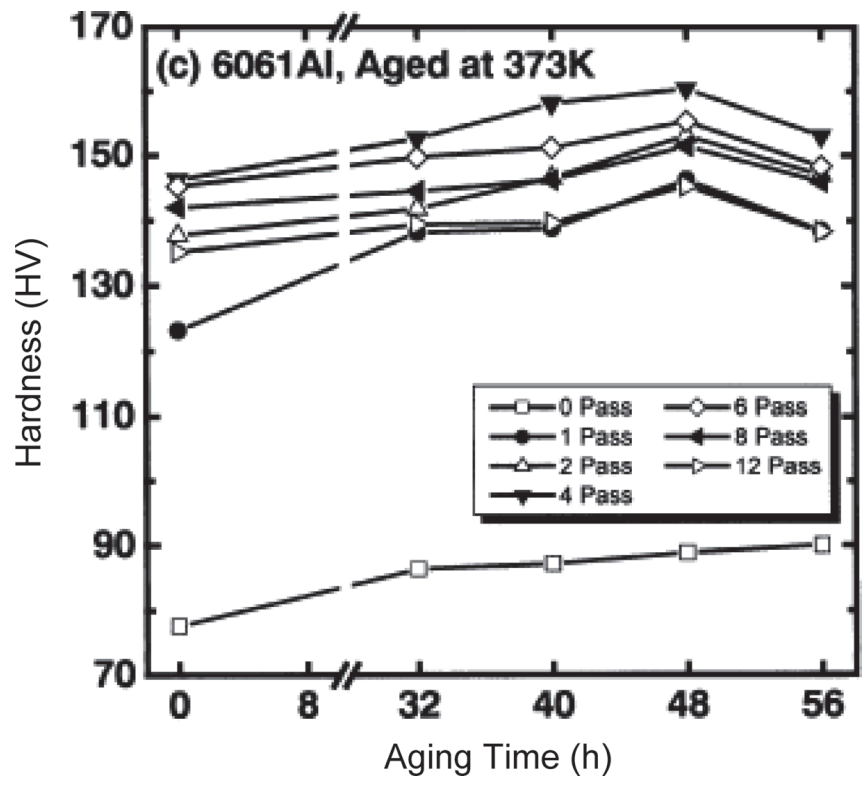

図4 ECAP加工した 6061 合金の $373 \mathrm{~K}$ 時効に伴う硬さ変 化 ${ }^{18}$ 

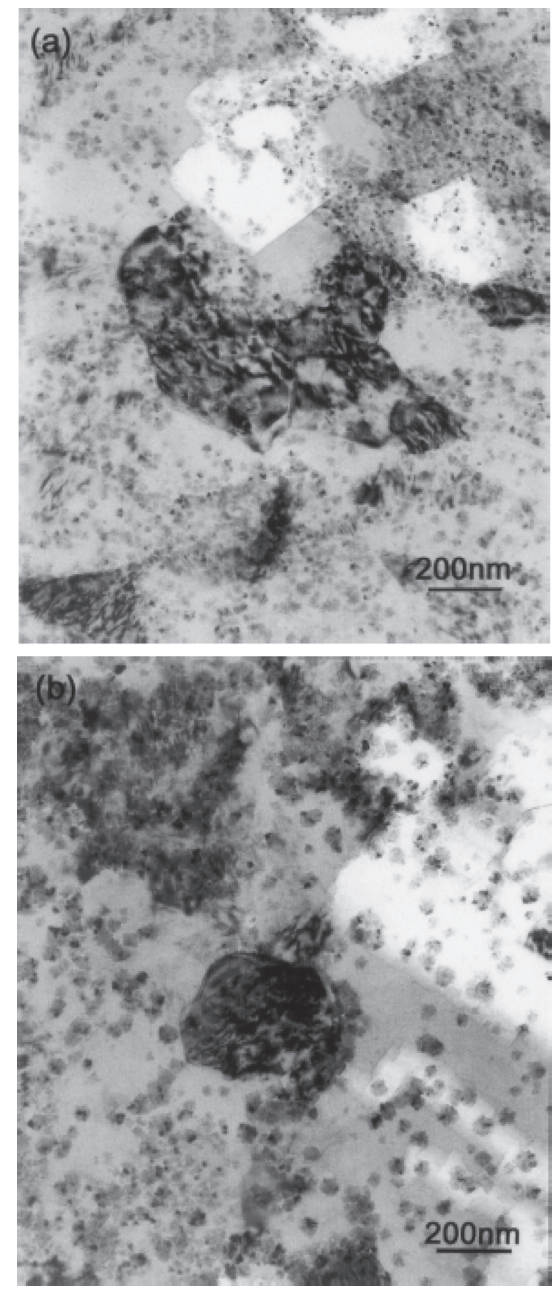

図 5 ECAP加工した 6061 合金を $373 \mathrm{~K} て ゙ 48 \mathrm{~h}$ 時効した ときの TEM 組織 ${ }^{18)}$ ：(a) 4 パス材，(b) 12 パス材

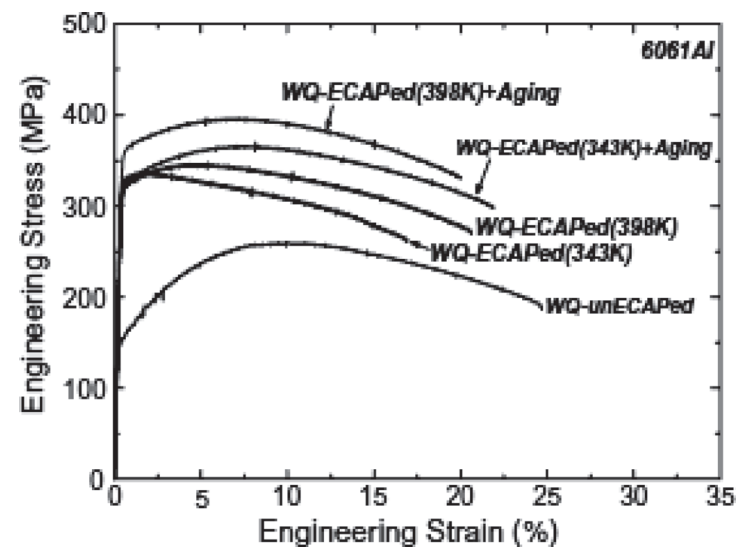

図6 6061合金を各指定の条件下で引張試験したときの 応力ーひずみ曲線 ${ }^{19)}$

6061 合金で同様な結果を報告しており，ECAP後の時効で強 度が上昇することを確認している。

著者らは，6061合金に付与ひずみを制御した状態で時効 挙動を調べ，Kim ら ${ }^{18)}$ が報告した結果と同じように，大量 のひずみの導入は必ずしもその後の時効に効果的ではないこ とを示した ${ }^{21)}$ 。図7は6061合金にHPT加工を施し $373 \mathrm{~K} て ゙$ 時 効したときの硬化量の変化を示したものである ${ }^{21)}$ 。 HPT加 工時の回転数は 0.75 回で通常よりも少ない回転数としてい

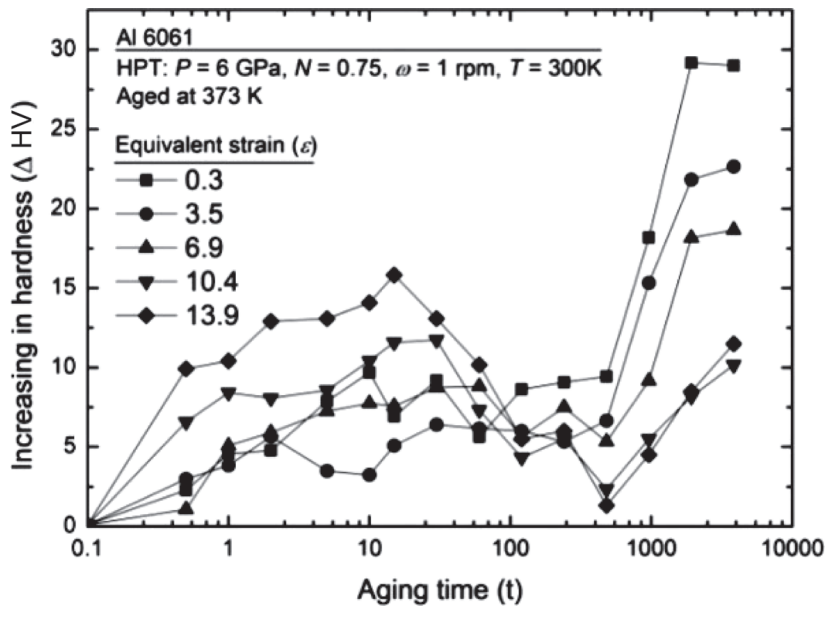

図 76061 合金を HPTで 0.75 回転したのち $373 \mathrm{~K} て ゙$ 時効 したときの付与ひずみ（ディスク中心からの距離） に応じた硬化量の変化 ${ }^{21)}$

る。デイスク状試料外周部のひずみ量が 13.9 の個所では短時 間後に硬化量が最大になるが，試料中心部付近のひずみ量が 0.3 の条件では硬化が顕著になるまでに時間がかかり, 最終 的には硬化量は付与ひずみ量が 13.9 の場合を超えて大きくな る。

著者らはさらに $\mathrm{Cu}, \mathrm{Ag}, \mathrm{Pd}, \mathrm{Pt}$ の第4元素を添加した時効硬 化型の $\mathrm{Al}-\mathrm{Mg}-\mathrm{Si}$ 合金にHPT加工を施し, 結晶粒微細化強化

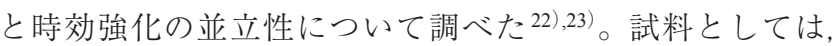
$\mathrm{Al}-1.0 \mathrm{mass} \% \mathrm{Mg}_{2} \mathrm{Si}$ のバランス組成と過剩 $\mathrm{Mg}$ 組成の $\mathrm{Al}-1.0 \mathrm{mass} \%$ $\mathrm{Mg}_{2} \mathrm{Si}-0.4 \mathrm{mass} \% \mathrm{Mg} に 0.5$ mass\% の $\mathrm{Ag}, \mathrm{Cu}$ ，あるいは $0.1 \mathrm{mass} \%$ のPt, Pdを添加したものである。詳細は本特集号で別途報告 した通りであるが23)，要約すると次のようになる。いずれ の合金も HPT加工で結晶粒は 300〜 430 nmに微細化され，引 続く $373 \mathrm{~K}$ の時効ではどの合金も時効によって硬化した。し かし, 時効に伴う硬さや硬化量の変化は添加元素の種類に よって大きく異なった。過剩 $\mathrm{Mg}$ 合金にCu を添加した場合, HPT加工による硬化は最も高く〜 $170 \mathrm{HV}$ となり, 引続く時 効で $0.6 \mathrm{ks}$ 後にピーク硬さの〜 $190 \mathrm{HV}$ まで増加した。TEM観 察によれば, 結晶粒内に析出物に起因する大きさ $10 \sim 20 \mathrm{~nm}$ のコントラストをもつ領域が確認されたが, 通常の溶体化処 理材の時効で観察されるような析出形態は観察されなかっ た。4種類の添加元素はいずれも $\mathrm{Mg}$ と引力型の相互作用が ある元素として知られているものである ${ }^{24)} 。 \mathrm{Cu}$ や $\mathrm{Ag}$ は無添 加のものに比べて一定の強化は得られたものの, $\mathrm{Pt} や \mathrm{Pd} の$ 添加では効果は小さく, むしろ長時間の時効では逆に軟化し た。巨大ひずみ加工材の時効挙動は, 添加元素と $\mathrm{Mg}$ との相 互作用だけでは十分に説明がつかないことが示された。

\section{Al-Zn-Mg-Cu系合金}

Zhaoら ${ }^{13)}$ は 7075 合金を $753 \mathrm{~K} て ゙ 5$ 時間溶体化処理した後, 2 パスのECAP加工を行い, 室温に 1 か月放置して自然時効 させ，ECAPしない溶体化試料の自然時効の結果と比較した。 引張試験後の応力ーひずみ曲線は図8に示すようで, ECAP 材の方が伸びは減少しているものの強度が 1.5 倍ほど高く なっている。TEM観察により, GPゾーンがECAP材の方で より多数できたためと結論している。ところで, Zhao ら ${ }^{13)}$ はECAP材を微細結晶粒組織（UFG）と称しているが，2パ 
スでは大角粒界を有する真のUFG 組織は得られないことか $ら^{25)}$ ，ここでの強度上昇は大角粒界の結晶粒ではなく亚結 晶粒の形成よるものと考えられる。さらに, Zhao ${ }^{14)}$ は $773 \mathrm{~K}$

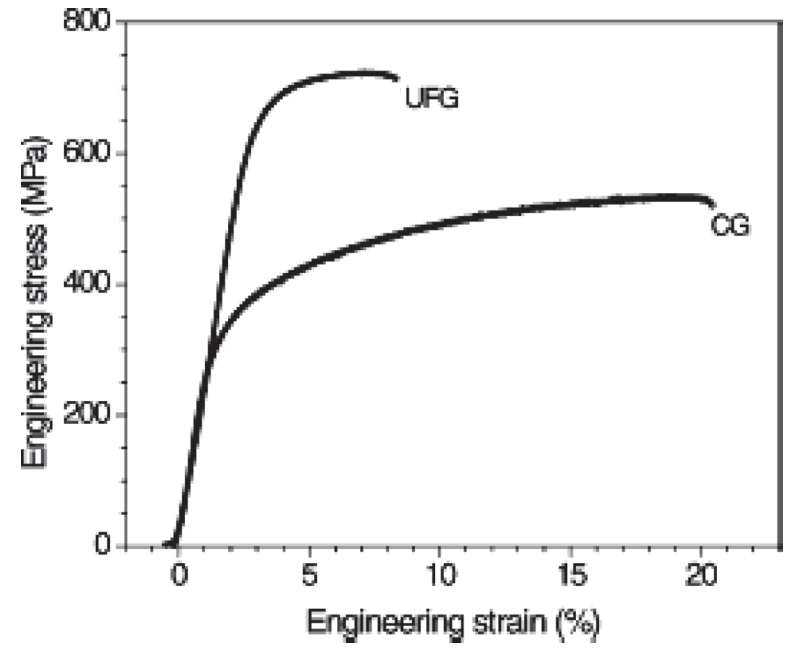

図8 溶体化処理した粗大粒（CG）7075合金とそれを ECAPで2パス加工 (UFG) し，それぞれ1か月室温 で自然時効した試料を引張試験したときの応力ー ひずみ曲線 ${ }^{13)}$

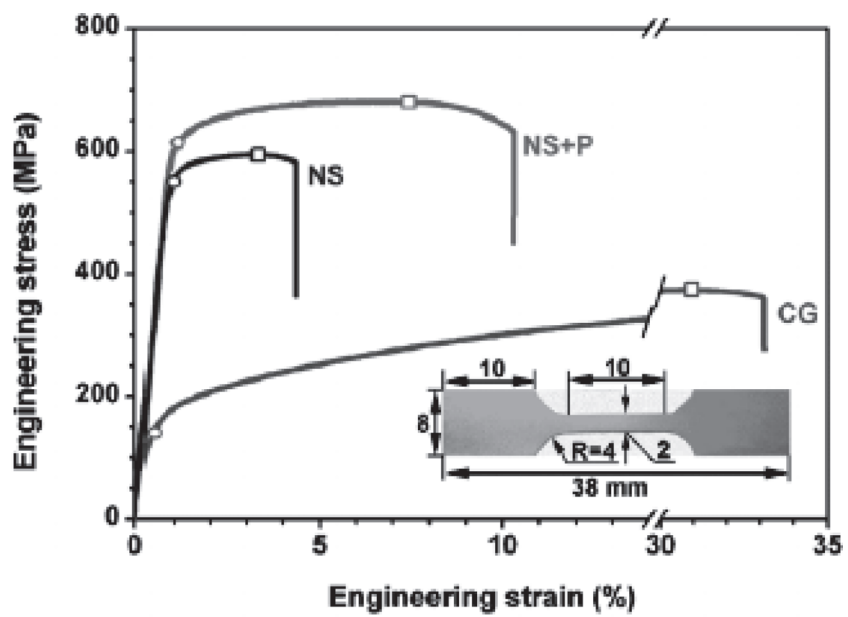

図9 溶体化処理した粗大粒（CG）7075 合金とそれを 極低温圧延した試料（NS）とその時効材 (NS+P を引張試験したときの応力ーひずみ曲線 ${ }^{14)}$

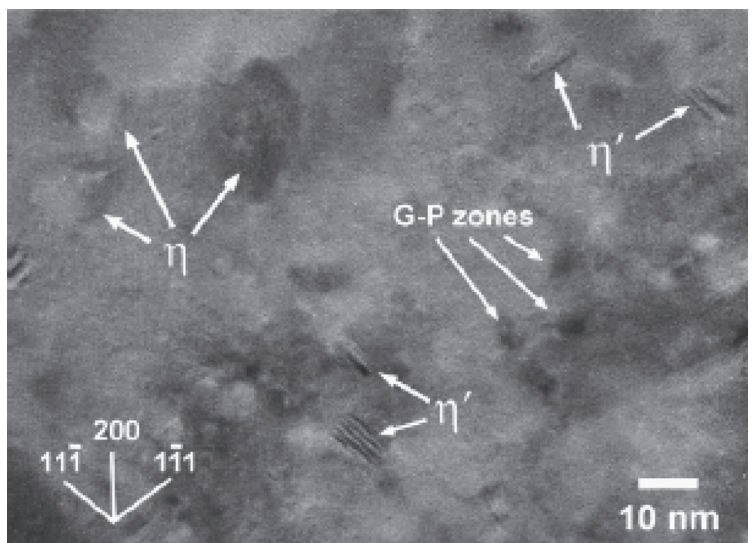

図 10 溶体化処理した 7075 合金を液体窒素中で極低温 圧延して時効したときの高分解能 TEM 像 ${ }^{14)}$
で溶体化処理した7075 合金を液体窒素中で極低温圧延して 約 $100 \mathrm{~nm}$ の微細粒組織としたのち， $323 \mathrm{~K} て ゙ 5$ 時間, さらに $353 \mathrm{~K}$ で9時間時効した。図9は室温での引張試験で得られた 応力ーひずみ曲線で，極低温圧延後の時効材は，極低温圧延 材の結果と比較して, 強度のほかに伸びも改善する。高分解 能TEMでの観察によれば，図 10 に示されるように微細粒内 にGPゾーンや $\eta^{\prime}$ 相の形成が認められる ${ }^{14)}$ 。結晶粒微細化と ともに時効析出は強度と伸びの同時改善に有効となる。結晶 粒界がどの程度大角化しているかについては明らかではない が，両強化の並立は強度と延性の同時向上に効果的な結果と なっている。

7075 合金を溶体化処理後HPT加工して時効挙動を調べた 結果はすでに解説記事で取上げており26),27), HPS加工を適 用した結果についても本特集号で詳細に報告した ${ }^{28)}$ 。いず れの巨大ひずみ加工も大幅な強度上昇が観察され，引続く時 効処理でさらに硬化した。TEM観察によれば，結晶粒径は 約 $300 \mathrm{~nm}$ あるいはそれ以下に微細化され， $373 \mathrm{~K}$ の時効でも 結晶粒は微細なまま存在した。高分解能 TEM観察によれば, $\eta^{\prime}$ 相や $\eta$ 相の析出粒子が観察され, 巨大ひずみによる結晶粒 微細化強化と時効による析出強化の並立が確認された。HPT 加工十時効 $(373 \mathrm{~K})$ では引張強さが $930 \mathrm{MPa}$ に達し, 破断

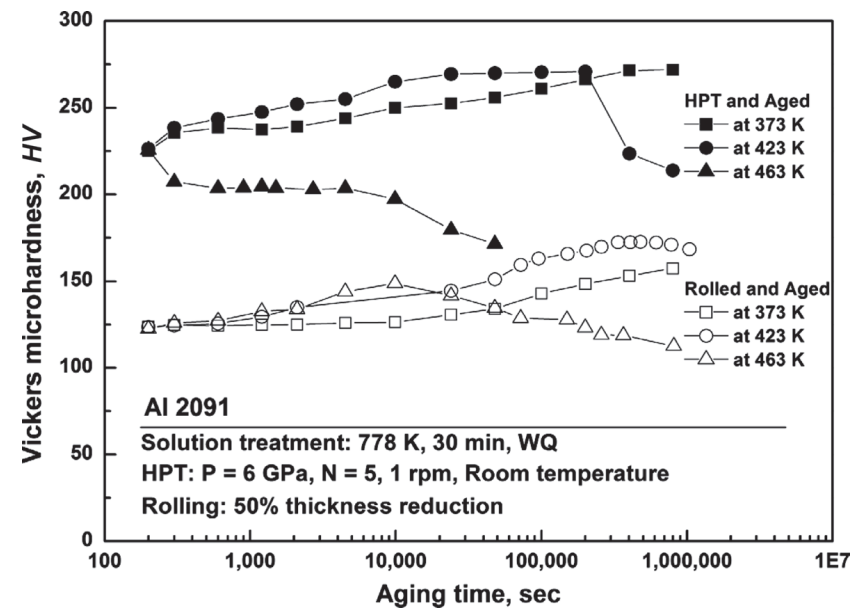

図 112091 合金の HPT材および50\%冷延材の時効に伴 う硬さ変化 ${ }^{30)}$

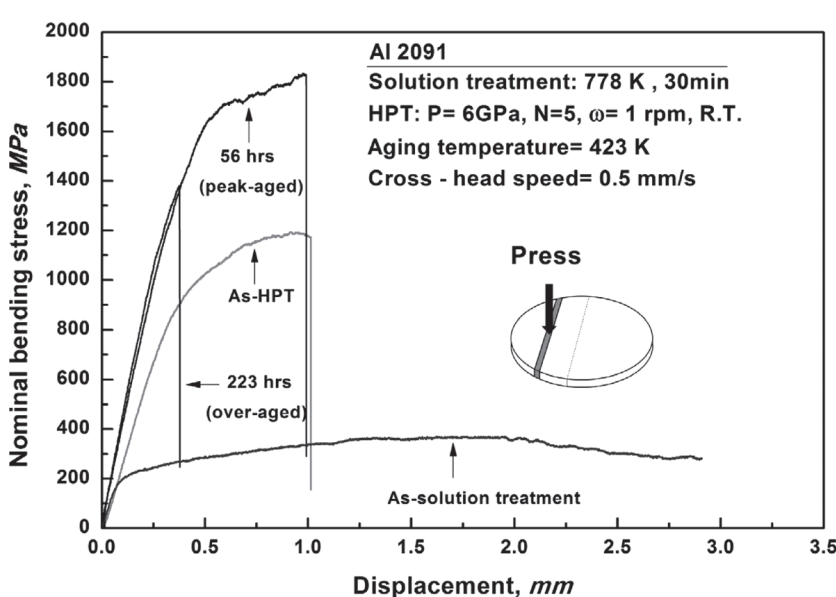

図 122091 合金の溶体化材, HPT材およびHPT後 $423 \mathrm{~K}$ で56時間ピーク時効および223時間過時効した ときの曲げ応力と変位との関係 ${ }^{30}$ 

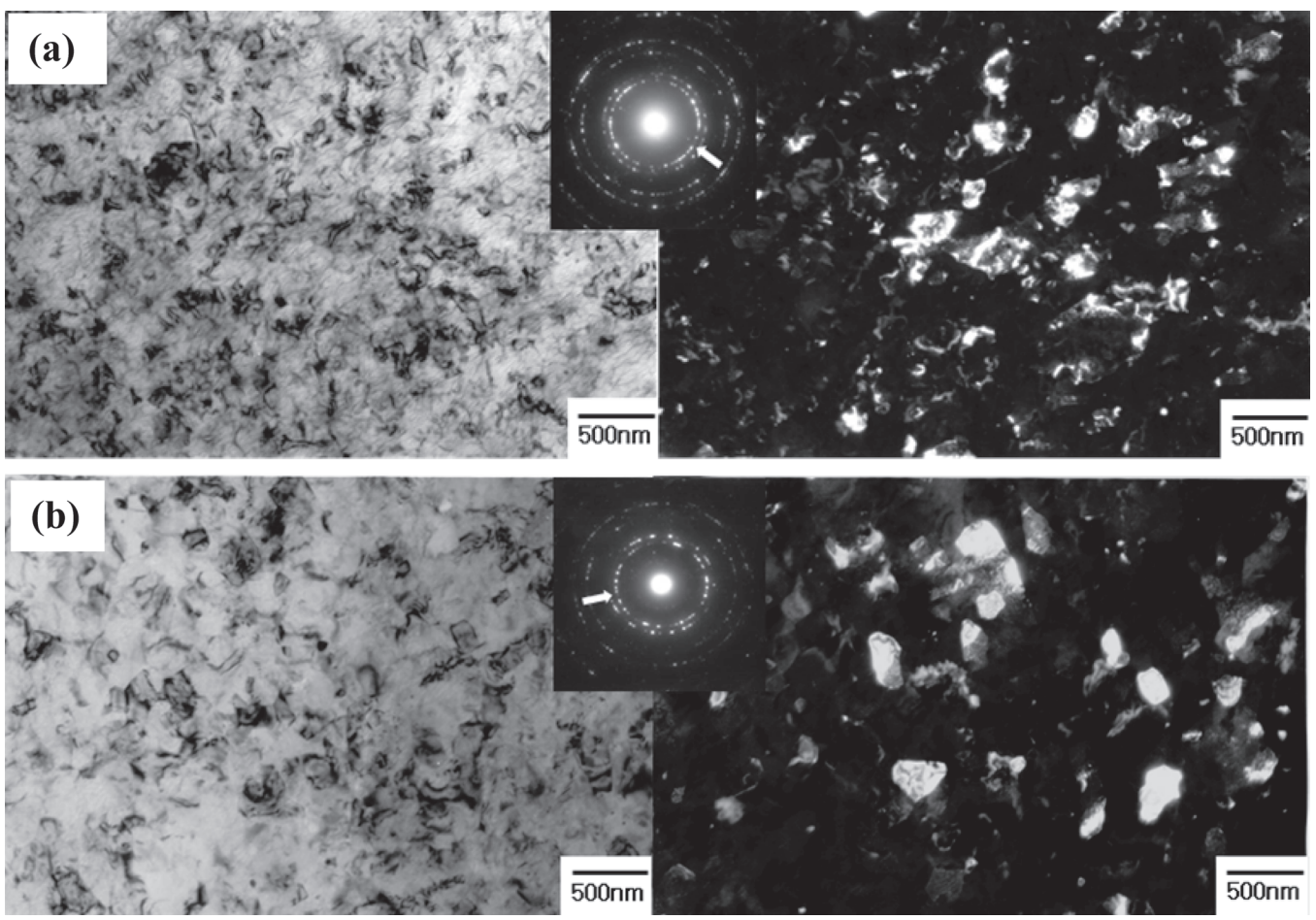

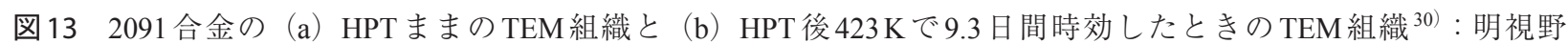
像 (左), 暗視野像 (右), 制限視野回折パターン (中) ${ }^{30)}$
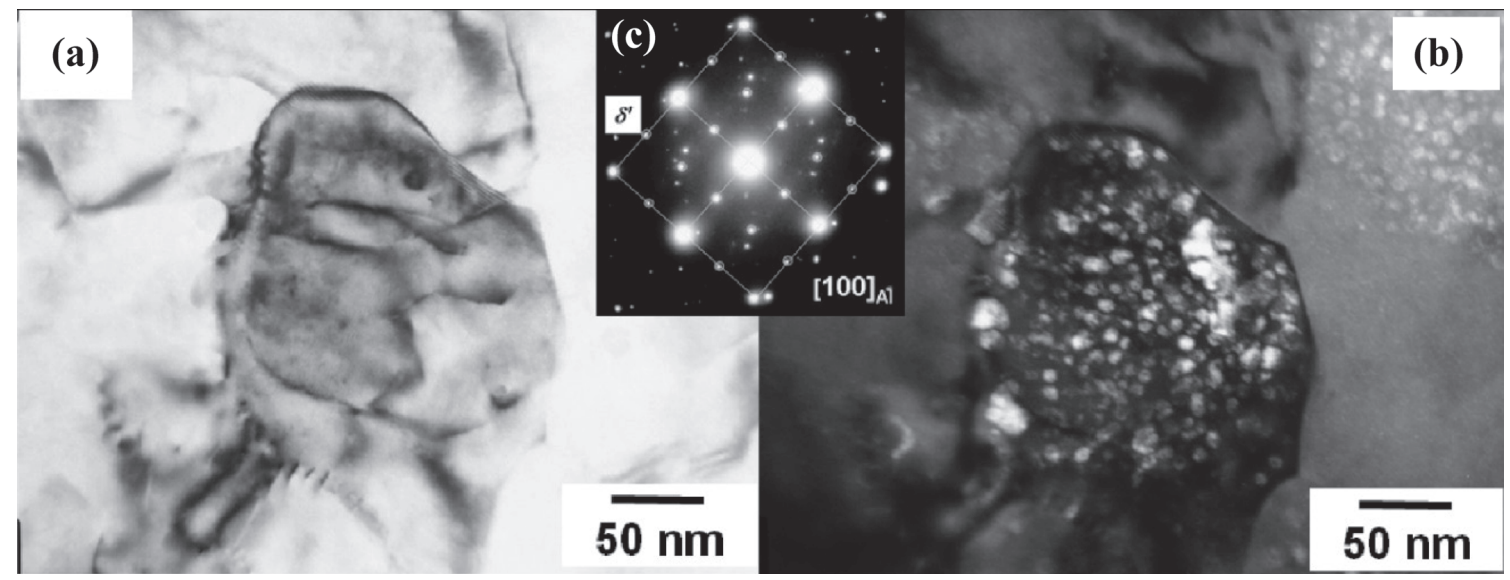

図 142091 合金を HPT 後423K で9.3 日間時効したときの TEM組織 ${ }^{30)} ：$ （a）明視野像，（b）暗視野像，(c）制限視野 回折パターン 30 )

伸び $2 \%$ が得られ ${ }^{26), 27)}$, HPS 加工＋時効 $(373 \mathrm{~K})$ では $750 \mathrm{MPa}$ と $5 \%$ の引張強さと破断伸びが得られた ${ }^{28)}$ 。

\section{5. $\mathrm{Al}-\mathrm{Li}-\mathrm{Mg}-\mathrm{Cu}$ 系合金}

最も軽量な金属であるリチウム $(\mathrm{Li})$ の添加は $\mathrm{Al}$ 合金の 軽量化とともに，剛性率の向上や $\delta^{\prime}-\mathrm{Al}_{3} \mathrm{Li}$ 相の析出で高強度 が狙えるとして盛んに研究が行われてきた ${ }^{29)}$ 。2091合金は $\mathrm{Li}$ ともに $\mathrm{Cu}$ や $\mathrm{Mg}$ を含む典型的な時効析出合金として知 られている。著者らは合金組成が $\mathrm{Al}-2.09 \% \mathrm{Li}-1.99 \% \mathrm{Cu}-$ $1.55 \% \mathrm{Mg}-0.12 \% \mathrm{Zr}-0.03 \% \mathrm{Si}-0.05 \% \mathrm{Fe}-0.03 \% \mathrm{Ti}$ (mass\%) の 2091 合金を溶体化処理後, HPT加工して時効処理し時効挙動を調 べた ${ }^{30)}$ 。 HPT加工のような巨大ひずみ加工では一般にひず みを増やしても硬さレベルが一定の定常状態に到達する31。 図 11 はこの定常状態の硬さレベルを時効時間に対してプ ロットしたものである ${ }^{30)}$ 。HPT加工後 $373 \mathrm{~K}$ と $423 \mathrm{~K}$ で時効
した試料では，明らかに硬さが増加しており，時効硬化が生 じている。50\%圧延材でも，同様の時効硬化は生じているが, 硬さレベルに $100 \mathrm{HV}$ 以上の差があり, HPT材がはるかに大 きい。図 12 は2091合金の溶体化材, HPT材, HPT 後のピー ク時効材および過時効材の曲げ応力と変位との関係を示した ものである ${ }^{30)}$ 。硬さ試験の結果と一致して, ピーク時効材 で強度が高くなり，過時効材で減少している。また，この曲 げ試験より HPT 材やピーク時効材で明確な塑性変形が生じ ている。

図 13 は $423 \mathrm{~K} て ゙ 9.3$ 日間過時効状態まで時効したときの透 過電子顕微鏡組織で ${ }^{30)}$, 右側の暗視野像から結晶粒径は $165 \mathrm{~nm}$ と測定された。9.3日間の長時間時効にもかかわらず 微細結晶粒径は保持されたままである。図 14 は $423 \mathrm{~K} て ゙ 9.3$ 日間時効したときの明視野像, 暗視野像, 制限視野回折パ ターンで, 暗視野像から微細結晶粒内には $\delta^{\prime}$ の微細な析出粒 
子が多数存在していることが観察される ${ }^{30) 。 ~}$

以上, 硬さ試験と透過電子顕微鏡による組織観察から, 2091 合金では，微細結晶粒内に $\delta^{\prime}$ 相の微細粒子が形成して おり, 結晶粒微細化強化と析出強化が同時に並立しているこ とが明らかになった。しかも曲げ試験より，時効による高強 度化とともに，塑性変形が十分確保されることがわかった。

\section{6. $A l-A g$ 系合金}

$\mathrm{Al}-\mathrm{Ag}$ 系合金は高温と低温における $\mathrm{Al}$ 中の $\mathrm{Ag}$ の固溶量の 差が大きく，典型的な析出硬化型合金として知られている。 図 15 は, Al-11 mass \% Ag 合金を $823 \mathrm{~K}$ で1 時間溶体化処理後, 室温にてECAPで 8 パス加工し， $373 \mathrm{~K}$ と $473 \mathrm{~K} て ゙$ 時効したと

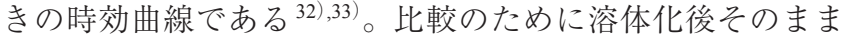
時効した場合（溶体化（ST）材），および溶体化後 $70 \%$ の冷 間圧延を施し $373 \mathrm{~K}$ で時効したときの結果も示す（冷間圧 延（CR）材）。 $473 \mathrm{~K}$ の時効では, 溶体化材は典型的な時効

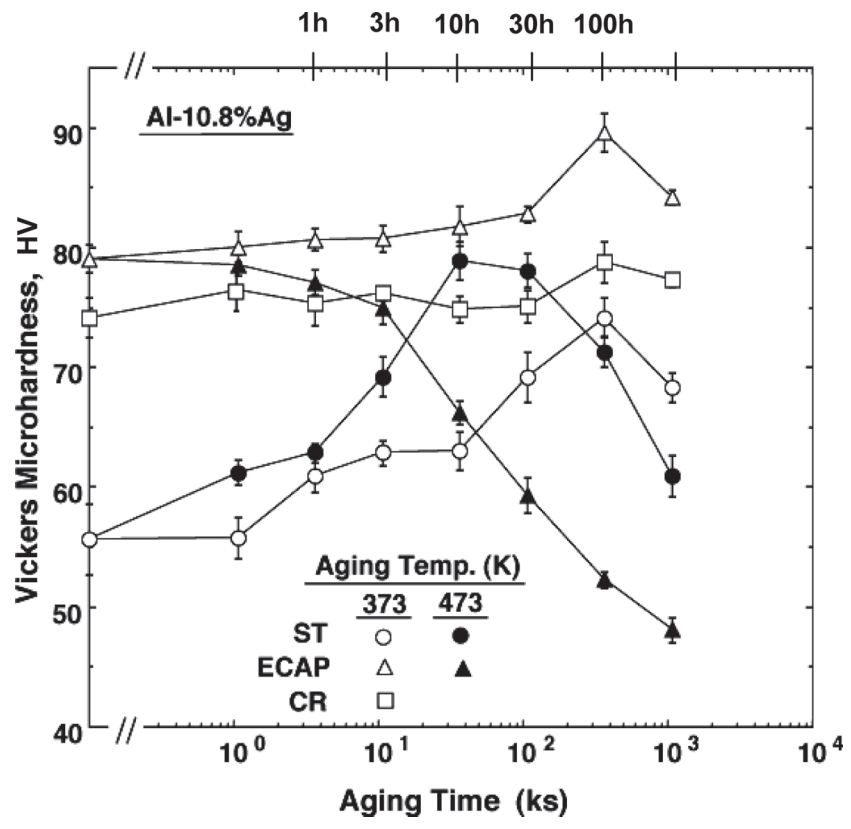

図15 Al-11 mass\% Ag 合金の溶体化材，ECAP材，冷間

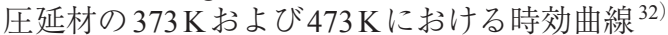

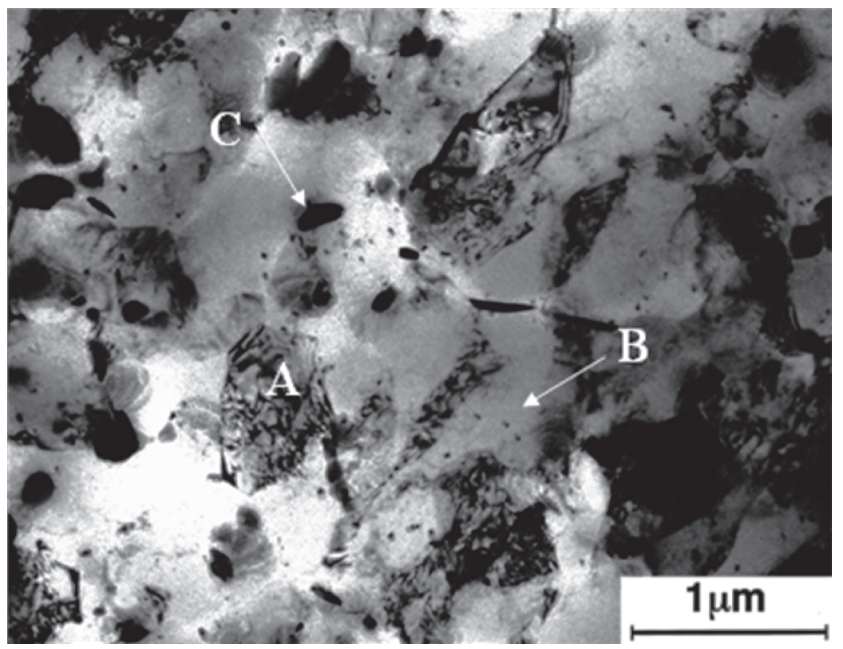

図 $16 \mathrm{Al}-11$ mass\% Ag 合金の ECAP材を $373 \mathrm{~K} て ゙ 100$ 時 間時効したピーク時効時の TEM 組織 32 )
硬化曲線を示すのに対して, ECAP材は硬さが減少し時効硬 化は見られない。一方， $373 \mathrm{~K}$ 時効では，溶体化材と ECAP 材ともに硬さの増加が見られ，100h時効でピーク值を示し た。冷間圧延材を時効した場合は溶体化材を時効した場合よ りも硬さ值は高いものの，時効硬化挙動は明瞭に見られず， ECAP材を $373 \mathrm{~K}$ で時効したときより低い硬さ值となってい る。ECAPで巨大ひずみを付与することで高い硬さレベルを 保持したまま， $373 \mathrm{~K}$ のような比較的低い温度で時効するこ とで時効硬化が図られることになる。

図 16 はECAP材を $373 \mathrm{~K} て ゙ 100 \mathrm{~h}$ 時効したピーク時効時の TEM組織である ${ }^{32)}$ 。長時間の時効でも図中 Aで示すように $1 \mu \mathrm{m}$ 以下の微細な結晶粒が保持され，その微細結晶粒内には Bで示すように直径数十 $\mathrm{nm}$ の球状粒子が析出している。ま た，結晶粒界にはCで示すように比較的大きな粒子が存在す る。この粗大な粒子は $\gamma$ 安定相でマトリックスとの整合性は みられない。図17は微細な結晶粒内を高倍率で観察したも のである ${ }^{32)}$ 。図中 A, Bで示すように球状粒子（

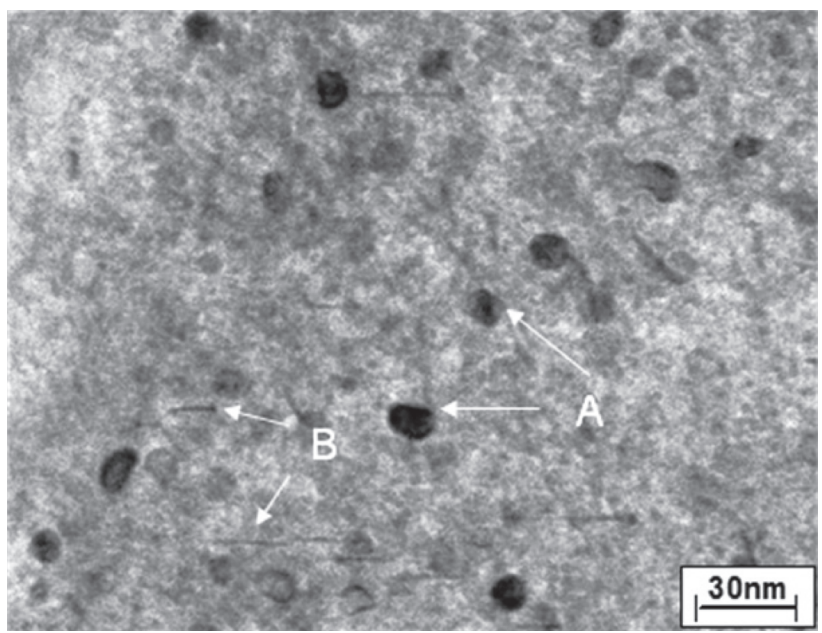

図 $17 \mathrm{Al}-11$ mass\% Ag 合金の ECAP材を $373 \mathrm{~K}$ で 100 時 間時効したピーク時効時における微細結晶粒内 の高倍率 TEM 組織 32

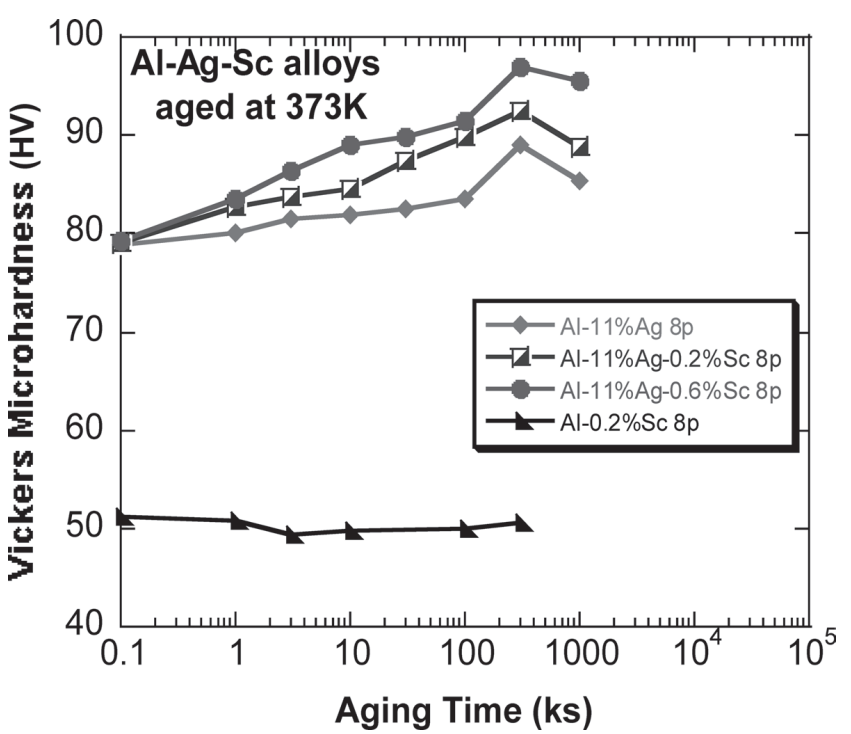

図 $18 \mathrm{Sc}$ 添加した純 $\mathrm{Al}$ および $\mathrm{Al}-11$ mass $\% \mathrm{Ag}$ 合金の ECAP材を $373 \mathrm{~K}$ で時効したときの硬さ変化 ${ }^{35}$ 

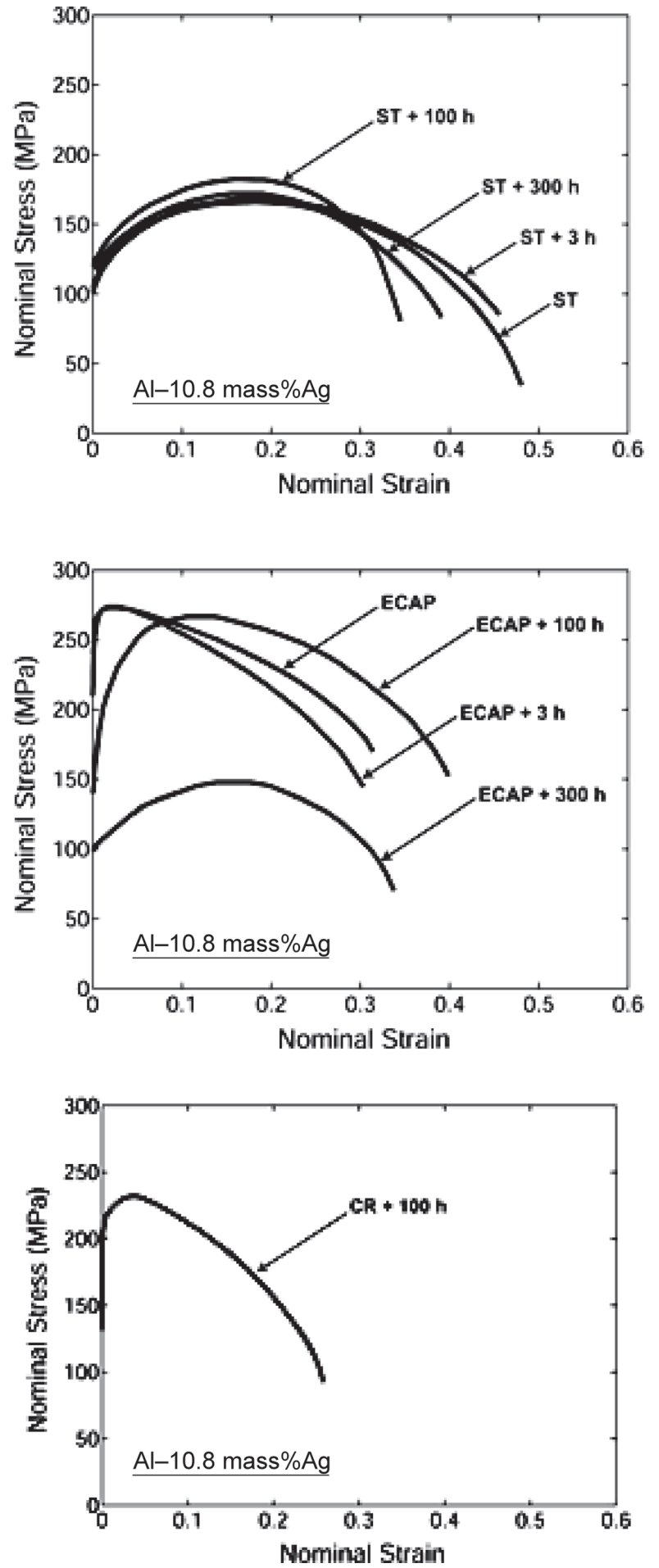

図 19 Al-11 mass\% Ag 合金の溶体化材 (ST), ECAP 材 (ECAP), 冷間圧延材 (CR) を $373 \mathrm{~K}$ で時効 したときの応力ーひずみ曲線 ${ }^{33)}$

一方向に伸びた板状ナノ粒子（ $\gamma^{\prime}$ 相）の存在が確認される。 したがって，Al-11 mass\% Ag 合金はECAP加工で結晶粒を超 微細化し $373 \mathrm{~K} て ゙$ 時効すると, 結晶粒微細化強化に重畳して 時効による析出強化を図ることができる ${ }^{32)}$ 34)。

図 18は Al-11 mass\% Ag 合金に 0.2 mass\% Sc あるいは 0.6mass \% $\mathrm{Sc}$ 添加した溶体化試料，あるいは $\mathrm{Ag}$ を添加せず，単に

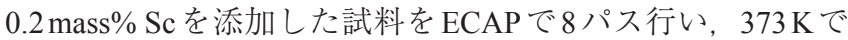
時効したときの硬さ変化を調べたものである ${ }^{35)}$ 。Sc 添加に より，またその添加量を 0.2 mass\% \%ら 0.6 mass\% まで増やす
ことにより，ECAP後の時効硬化量は増大する。一方で, $\mathrm{Ag}$ 添加がなく $0.2 \mathrm{mass} \% \mathrm{Sc}$ の添加のみでは時効硬化は見られ ず, $\mathrm{Ag}$ と $\mathrm{Sc}$ の両添加が重要となる。

図 19 は Al-11 mass\% Ag 合金の溶体化材, ECAP材および それぞれ $373 \mathrm{~K} て ゙$ 時効処理した試料を室温にて $1.0 \times 10^{-3} \mathrm{~s}^{-1}$ の ひずみ速度で引張試験を行った結果である。溶体化材の時効 では破断伸びが確保されるが十分な強度上昇は得られず, ECAP加工ままでは強度は大きく増加するが均一伸びが得ら れていない。ECAP材を硬さのピーク值まで100時間時効し た試料では, ECAP加工による高強度を保ったまま均一伸び が向上し, 両特性が同時に大きくなるという金属材料一般に とっては極めて重要な現象が実現されている。図には70\% 圧延材を $373 \mathrm{~K} て ゙ 100$ 時間時効した結果も示しているが, 強 度と均一伸びはいずれも ECAP材をピーク值まで時効した場 合に比べると小さい。ECAP材の時効では微細な結晶粒径を 保ったまま粒内に微細粒子が析出したこと, さらには, 加工 によって導入された転位が，100 時間の時効時間中に消滅し たことなどが, 強度と延性の同時向上に繋がったものと考え られる。

Lee と Horita は 3 種類の Al-Ag 合金（Al-5 mass\% Ag, Al11 mass\% Ag, Al-20 mass\% Ag）を作製し 823 Kで 1 時間溶体化 処理後にHPT加工を行い, さらに3つの温度 $(323,348$, $373 \mathrm{~K}$ ）で時効処理を行って, 時効挙動を調べた ${ }^{36)}$ 。HPT加 工ではピーク強度に達する時間がかなり短時間側にシフトす る以外は，基本的にECAPの場合と同じ傾向が得られ，結晶 粒微細強化と時効による析出強化の並立が得られた。また, ピーク時効後の引張試験では HPT ままの試料に比べて引張 強さも延性も改善する結果が得られている。

\section{7. おわりに}

巨大ひずみ加工による結晶粒微細化強化と時効による析出 強化の並立は適切な加工条件と時効条件を設定することで基 本的に可能である。最近, 増田らによって計算科学的にこれ らの条件を絞込む試みがなされている ${ }^{37)}$ 。空孔, 転位, 結 晶粒界など格子欠陥が高密度で存在する中での原子拡散速度 の算定や析出の駆動力の算定など, 詳細な調整は必要とされ るものの, 今後計算科学を駆使した加工・熱処理の条件設定 が材料組成も含めてより高精度でできるようになれば，結晶 粒微細化強化と析出強化の並立に対する予測が可能になると 期待される。

巨大ひずみ加工による結晶粒微細化は多量の格子欠陥の導 入を伴うものであるが，結晶粒界角が必ず大角状態でなけれ ばならないかについては今後検討が必要である。必ずしも大 角粒界に囲まれた微細結晶粒でなく亜結晶粒状態でも，時効 による析出強化は効果的に進行する場合があり, 系統的な研 究が望まれるところである。

本解説では, 結晶粒を巨大ひずみ加工で超微細化してお き, その後の時効で微細結晶粒内に細かい粒子を析出させよ うとする試みを中心にまとめた。しかしながら，このような 特殊な微細組織の創製は必ずしも結晶粒微細化から時効析出 の順序でする必要はなく, まず時効して析出粒子の分散を図 り, その後巨大ひずみ加工で強制的に析出粒子を分断・分散 させることも考えられる ${ }^{38)}$ 。あるいは, 巨大ひずみ加工温 度を高めにした状態でひずみの導入と析出を同時に進行させ 
ることもある。加工温度やひずみ量など適切な制御条件の設 定は, 今後の重要な研究課題と考える。

本研究では，析出はもっぱら核生成・成長型を前提に論じ ているが，廣澤らは，スピノーダル分解が起こる場合はどう

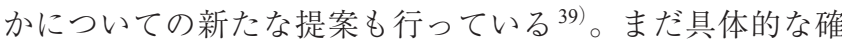
認には至っていないが，微細結晶粒内に第 2 相粒子を均一に 分散させる効果的な組織制御法と考えられる。

最後に, 微細結晶粒中での粒子分散は, 結晶粒微細化強化 と析出強化の並立によって高強度化するとともに，延性確保 にも結びつく可能性がある。微細粒子の分散で加工硬化指数 が高くなり均一伸びが大きくなるのが原因と考えられるが, 同時に結晶粒界が転位の発生源および消滅箇所になって，転 位の活動が活発になることも一因と考えられる。一般にト レードオフの関係にしかならない強度と延性が同時に確保で きることは，材料開発が本質的に求めるところである。結晶 粒微細化強化と析出強化の並立は強度と延性の同時向上にも 効果的であり, これからの系統的な研究が期待されるところ である。

\section{謝 辞}

本研究は，（独）科学技術振興機構（JST）産学共創基礎 基盤研究「へテロ構造制御」の支援を受けて行われたもので ある。また研究の一部は, 公益財団法人軽金属奨学会統合的 先端研究, および文部科学省科学研究費新学術領域研究「バ ルクナノメタル」の一環として行われたものである。ここに 記して謝意を表する。

\section{参 考 文 献}

1) R. Z. Valiev, Y. Estrin, Z. Horita, T. G. Langdon, M. J. Zehetbauer and Y. T. Zhu: JOM, 58 (2006), 33-39.

2) R. Z. Valiev, R. K. Islamgaliev and I. V. Alexandrov: Prog. Mater. Sci., 45 (2000), 103-189.

3) A. P. Zhilyaev and T. G. Langdon: Prog. Mater. Sci. 53 (2008), 893.

4) R. Z. Valiev and T. G. Langdon: Prog. Mater. Sci., 51 (2006), 881.

5) Y. Zhu, R. Z. Valiev, T. G. Langdon, N. Tsuji and K. Lu: MRS Bull., 35 (2010), 977.

6) V. M. Segal, V. I. Reznikov, A. E. Drobyshevskiy and V. I. Kopylov: Russian Metall., 1 (1981), 99-105.

7) P. W. Bridgman: Phys. Rev., 48 (1935), 825.

8) Y. Saito, H. Utsunomiya, N. Tsuji and T. Sakai: Acta Mater., 47 (1999), 579-583.

9) O. R. Valiakhmetov, R. M. Galeyev and G. A. Salishchev: Fiz. Met. Metalloved, 10 (1990), 204

10) Y. Harai, Y. Ito and Z. Horita: Scr. Mater., 58 (2008), 469-482

11) T. Fujioka and Z. Horita: Mater. Trans., 50 (2009), 930-933.
12) Y. Wang, M. Chen, F. Zhou and E. Ma: Nature, 419 (2002), 912-915.

13) Y. H. Zhao, X. Z. Liao, Z. Jin, R. Z. Valiev and Y. T. Zhu: Acta Mater., 52 (2004), 4589-4599.

14) Y. H. Zhao, X. Z. Liao, S. Cheng, E. Ma and Y. T. Zhu: Adv. Mater., 18 (2006), 2280-2283.

15) S. Cheng, Y. H. Zhao, Y. T. Zhu and E. Ma: Acta Mater., 55 (2007), 5822-5832.

16) N. Tsuji, T. Iwata, M. Sato, S. Fujimoto and Y. Minamino: Sci. Technol. Adv. Mater., 5/1-2 (2004), 173-180.

17）米永洋介, 堀田善治: 軽金属学会第 123 回秋期大会講演概 要, (2012), 387-388.

18） W. J. Kim, J. K. Kim, T. J. Park, S. I. Hong, D. I. Kim, Y. S. Kim and J. D. Lee: Metall. Mater. Trans. A, 33 (2002), 3155-3164.

19) J. K. Kim, H. K. Kim, J. W. Park and W. J. Kim: Scr. Mater. 53 (2005), 1207-1211.

20) X. Sauvage, M. Yu. Murashkin and R. Z. Valiev: Kovove MaterialyMetallic Materials 49 (2011), 11-15.

21） I. F. Mohamed, S. Lee and Z. Horita: 軽金属学会第 123 回秋期大会 講演概要, (2012), 63-64.

22) D. Akama, Z. Horita, K. Matsuda and S. Hirosawa: Materials Science Forum, 667-669, (2011), 259-264

23）赤間大地，李 昇原，堀田善治，松田健二，廣澤涉一：軽金属, 62 (2012)，448-453

24）廣澤涉一，中村文滋，里 達雄，星野敏春：軽金属， 56 (2006）, 621-628.

25) Y. Iwahashi, Z. Horita, M. Nemoto and T. G. Langdon: Acta Mater., 46 (1998), 3317-3331.

26）堀田善治：軽金属, 60 (2010), 134-141

27) Z. Horita: Proceedings of the 12th International Conference on Aluminium Alloys (ICAA12), eds. by S. Kumai, O. Umezawa, Y. Takayama, T. Tsuchida, T. Sato, The Japan Institute of Light Metals, (2010), 40-45.

28）田添聖誠, 堀田善治：軽金属，62 (2012)，454-458

29）坂本敏正：軽金属, 46 (1996), 344.

30) S. Lee, Z. Horita, S. Hirosawa and K. Matsuda: Mater. Sci. Eng. A, 546, (2012), 82-89.

31) K. Edalati and Z. Horita: Mater. Sci. Eng. A, 528 (2011), 7514-7523.

32) Z. Horita: Mater. Sci. Forum, 519-521 (2006), 1485-1492.

33) K. Ohashi, T. Fujita, K. Kaneko, Z. Horita and T. G. Langdon: Mater. Sci. Eng. A, 437 (2006), 240-247.

34) Z. Horita, K. Ohashi, T. Fujita, K. Kaneko and T. G. Langdon: Adv. Mater., 17 (2005), 1599-1602.

35） V. A. Mosneaga and Z. Horita: 軽金属学会第 110 回春期大会講演 概要, (2006)，111-112

36) S. Lee and Z. Horita: Metall. Mater. Trans. A (2012), submitted

37）増田哲也, 廣澤渉一, 堀田善治, 松田健二：日本金属学会誌, 75 (2011)， 283-290.

38) Z. Horita, K. Oh-ishi and K. Kaneko: Sci. Tech. Adv. Mater., 7 (2006), 649-654.

39）廣澤涉一, 濱岡 巧, 堀田善治, 李 昇原, 松田健二, 寺田大 将：ふえらむ，17(2012)，掲載予定 